\section{A REAL BIRD HOUSE}

In the spring of 1995 a pair of Northern Flickers arrived in the South Saskatchewan River valley north of Leader. They toured the Leaning Tree Guest Ranch owned and operated by Paul and Vivian Letkeman and selected a cosy cabin nestled beside large cottonwood poplars. The flickers proceeded to make their own private entranceway at the rear of the cabin, in the northwest corner, $5 \mathrm{ft}$. above the ground.

During the summer they could be seen coming and going. Happy chirping and twittering could be heard as they raised a family of young flickers in the nest site situated between the outer and inner walls of the cabin. After the flicker family had departed in the fall, Paul nailed a thick piece of board over the nest hole.

When the flickers arrived back at the Leaning Tree in the spring of 1996, they were pleased to see that Mr. Letkeman had taken such good care of their cabin by closing the entrance hole to keep it clean and dry. They proceeded to re-open the cabin for the summer by drilling through that thick board in the same hole as used in 1995. Happy chirping was once again heard from amid the walls of the cabin by the cottonwoods.

Acknowledgement Thanks to Paul and Vivian Letkeman for sharing this interesting story with me.

- Daisy D. Meyers, Box 218, Leader, SK. SON $1 \mathrm{HO}$

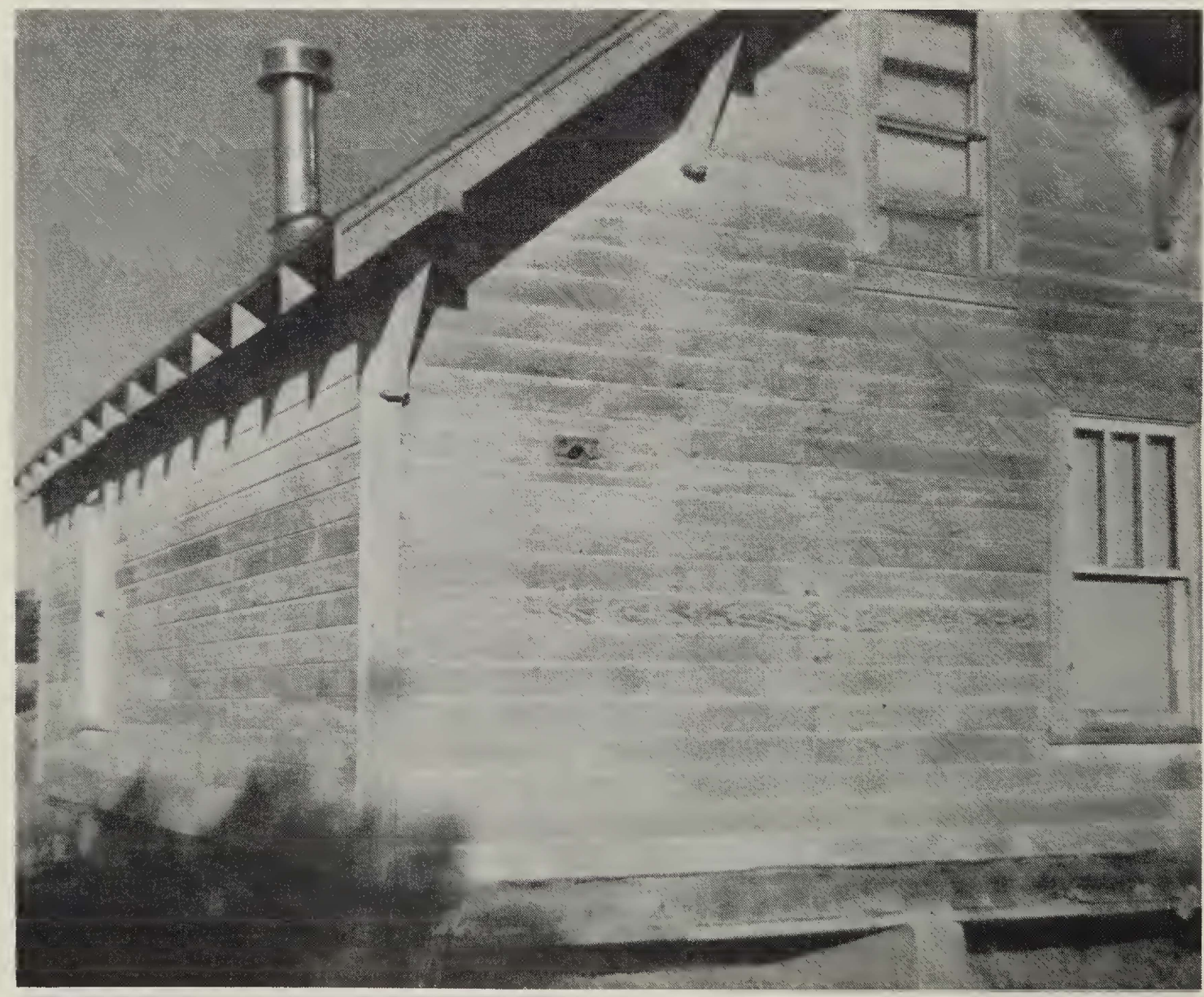

Northern Flicker nest hole in tourist cabin on Leaning Tree Guest Ranch northeast of Leader, SK.

Daisy D. Meyers 